\title{
Impact of indiscriminate disposal of untreated effluents in Korangi creek, Karachi, Pakistan
}

\author{
Aamir Alamgir ${ }^{1} \cdot$ Moazzam Ali Khan $^{1} \cdot$ S. Shahid Shaukat ${ }^{1} \cdot$ Jamil Hassan Kazmi $^{2}$
}

Received: 3 June 2017 / Accepted: 11 September 2018 / Published online: 18 September 2018

(c) The Author(s) 2018

\begin{abstract}
Korangi creek is one of the major creek of Indus delta which receives both untreated industrial and domestic effluents. It provides an important waterway to approach Port Qasim. A survey of water quality and the sediments along with biodiversity of benthic fauna was conducted. A total of 24 water and 14 sediment samples were collected from February to November 2014. The mean $\mathrm{pH}$ of seawater and sediment samples was 7.41 and 7.5 , respectively. The mean salinity of seawater was $36 \%$. The mean BOD5 of seawater and sediments was $288 \mathrm{mg} / \mathrm{l}$ and $1645 \mathrm{mg} / \mathrm{kg}$, respectively, while COD was $1231.9 \mathrm{mg} / \mathrm{l}$ and $1645.3 \mathrm{mg} / \mathrm{kg}$, respectively. Cyanide content was low in seawater but slightly higher in sediment. Mean phenol level of seawater and sediment was $0.61 \mathrm{mg} / \mathrm{l}$ and $8.11 \mathrm{mg} / \mathrm{kg}$. Heavy metals in the seawater was established to be in the order $\mathrm{Pb}>\mathrm{Cu}>\mathrm{Cr}>\mathrm{Ni}>\mathrm{Zn}>$ As. The trend in sediment was slightly different and followed the following pattern $\mathrm{Pb}>\mathrm{As}>\mathrm{Ni}>\mathrm{Cu}>\mathrm{Cr}>\mathrm{Zn}$. The distribution pattern of the estimated variables for seawater and sediments was examined using the principal component analysis and cluster analysis. Annelida and Arthropoda were the dominant components of biodiversity. Taxa diversity was measured and Shannon index $(H)$ ranged between 1.364 and 1.969 while equitability $(J)$ ranged between 0.549 and 0.862 . Dominance $(D)$ was in the range of $0.156-0.436$.
\end{abstract}

Keywords Untreated effluents $\cdot$ Creek $\cdot$ Pollution $\cdot$ Industrial effluents $\cdot$ Karachi

\section{Introduction}

Karachi is the capital of Sindh province that comprises of southwestern component of the Indus delta having a coastline of about $135 \mathrm{~km}$ (Khan et al. 2004). It is the biggest hub of industrial activities in Pakistan. There are about 10,000 industrial units in formal sector of assorted industries manufacturing paints, steel, fabrics, chemicals, paper and paper products, pharmaceuticals and foodstuff, etc. Karachi

Aamir Alamgir

aamirkhan.ku@gmail.com

Moazzam Ali Khan

sherwanis@hotmail.com

S. Shahid Shaukat

shahid_shaukat2007@yahoo.co.uk

Jamil Hassan Kazmi

jkazmi@usa.net

1 Institute of Environmental Studies, University of Karachi, Karachi 75270, Pakistan

2 Department of Geography, University of Karachi, Karachi 75270, Pakistan comprises of four major industrial zones including SITE (Sindh Industrial Trading Estate), LITE (Landhi Industrial Trading Estate), WWI (West Wharf Industries) and the KIA (Korangi Industrial Area) (Monawwar et al. 1999). There are a number of cottage industries working in informal sectors of the city. Only a few entrenched industries have installed rudimentary effluent treatment facilities, while most of the industrial units discharge their effluent into the Karachi coastal areas without any adequate treatment (Khan et al. 2012). The indiscriminate discharge of untreated domestic and industrial effluents is severely affecting rich and diverse tropical marine/estuarine ecosystem that is characterized by hypersaline tidal creeks.

On the south west of Karachi are the creeks of Indus delta which start from the Gharo creek. The creek area of Indus delta comprises of an area of 64,000 ha. that also includes Korangi-Phitti creeks (Meynell 1995). The Korangi creek is a tidal creek having high salinity values which are similar to that of seawater (Haq 1976). It is located at the south of Karachi and is interconnected up to Port Qasim which is the second major port of Pakistan. The creek is state-owned governed under the 
administration of Port Qasim Authority. The creek is connected with other small creeks out of which the important creeks are Kadiro, Jhari and Ganglaro. The creek area is navigable through small vessels. Parallel to the creek area is the hilly range starting from Ibrahim Haidry. Owing to its location and the influence of strong winds, it runs in the northeastern direction. The creek area also comprises of numerous fishing villages that include Rehri village, Ayub village, Ibrahim Haidery, Chashma village and village Jamot.

The first survey of the creek was conducted as early as 1952 (Husain 1988). Since then, the creek has not shown much diversion and maintained its shape and depth. However, in the past years, it has been noticed that the dredged material is being dumped close to its entrance. The most suitable time to enter in the creek area is about $2 \mathrm{~h}$ before high water.

It is noteworthy that it was formerly known as Kadiro river which was in fact the tributary of River Indus that carried fresh water. At present virtually it is tidal creek that also receives untreated waste of domestic and industrial origin from Korangi and Landhi Industrial zones. Similarly, the creek also receives untreated wastewater through Malir River. The discharge from cattle colony also increases heavy organic pollution load at the creek.

The heavy pollution discharge that reaches the mangrove area is responsible for serious environmental implications, for instance, the spawning ground for fishes are badly affected by the toxic pollutants. These effects are noticeable in terms of fisheries quality that has commercial importance (IUCN 2005; Shahzad et al. 2009; WWF 2000).

Korangi creek is $20 \mathrm{~km}$ in length, $1350 \mathrm{~m}$ wide and has average depth of 15 meters (Khatoon and Hussain 2006). However, according to the present investigation, the creek length is about $27 \mathrm{~km}$, while average depth and width are $12 \mathrm{~m}, 1.5 \mathrm{~km}$, respectively.

The creek also has its economic and social importance as it provides the livelihood of more than 100,000 people, which are directly or indirectly engaged in fisheries. There are 38 species of fishes recorded from Korangi creek.

The quantitative data of waterfowl of Korangi creek area that include 17 of the 30 waterbird species (Scott et al. 1989). However, Ward (1999) reported 27 bird species out of which many are threatened or vulnerable. Invertebrate species of crab, bivalve and gastropods are also found in the area (Ward 1999). Sea snake Enhydrina schistosa is also reported from the creeks.

It is with this aim the present research investigation was undertaken to know the extent of pollution load in Korangi creek whose impacts are known and likely to be significant for future populations.

\section{Materials and methods}

\section{Sampling}

The study period was from February to November 2014 during which twenty-four samples of both creek water and sediments were collected. Niskin bottle was used to collect grab water samples (approx. $10 \mathrm{~cm}$ ) from an area easily accessible through feet. This was approximately on an average $550 \mathrm{~m}$ from the shore. Water samples were collected carefully into white hardcore plastic containers for subsequent physicochemical analysis. The sample was preserved accordingly as mentioned in APHA (2005). Sterilized glass bottles were used for the collection of water samples for the microbiological analysis that were placed in an ice box without delay. Samples were obtained through deterministic sampling and their locations are presented in Fig. 1.

\section{Collection of sediment samples}

Figure 1 represents the sites of sediments sample collection. These samples were collected in sterile plastic bags using Patterson grab.

\section{Physical parameters}

The physical parameters of water were $\mathrm{pH}$, salinity and dissolved oxygen (DO) that were measured on site. $\mathrm{pH}$ of the samples (water and sediments) was ascertained using 156 multiparameter meter (HACH). Salinity was measured through INOLAB WTW meter. Jenway 630i dissolved oxygen meter was used for DO measurement.

\section{Biochemical and chemical parameters}

The biochemical and chemical parameters tested for creek water were (1) biochemical oxygen demand $\mathrm{BOD}_{5}$ and COD were measured through azide modification method and dichromate reflux method, respectively, according to APHA (2005). For COD analysis, HACH COD reactor was used. Chlorophyll in water samples was estimated using multiple optical density $(750,663,645,630)$ through spectrophotometer as per method of APHA (2005).

Distillation method was employed for cyanide and TKN estimation. Oil and grease (n-Hexane extract method) was estimated gravimetrically while photometric method was used for phenol estimation. For the sediment samples analysis, the above-mentioned parameters were used except for chlorophyll. 


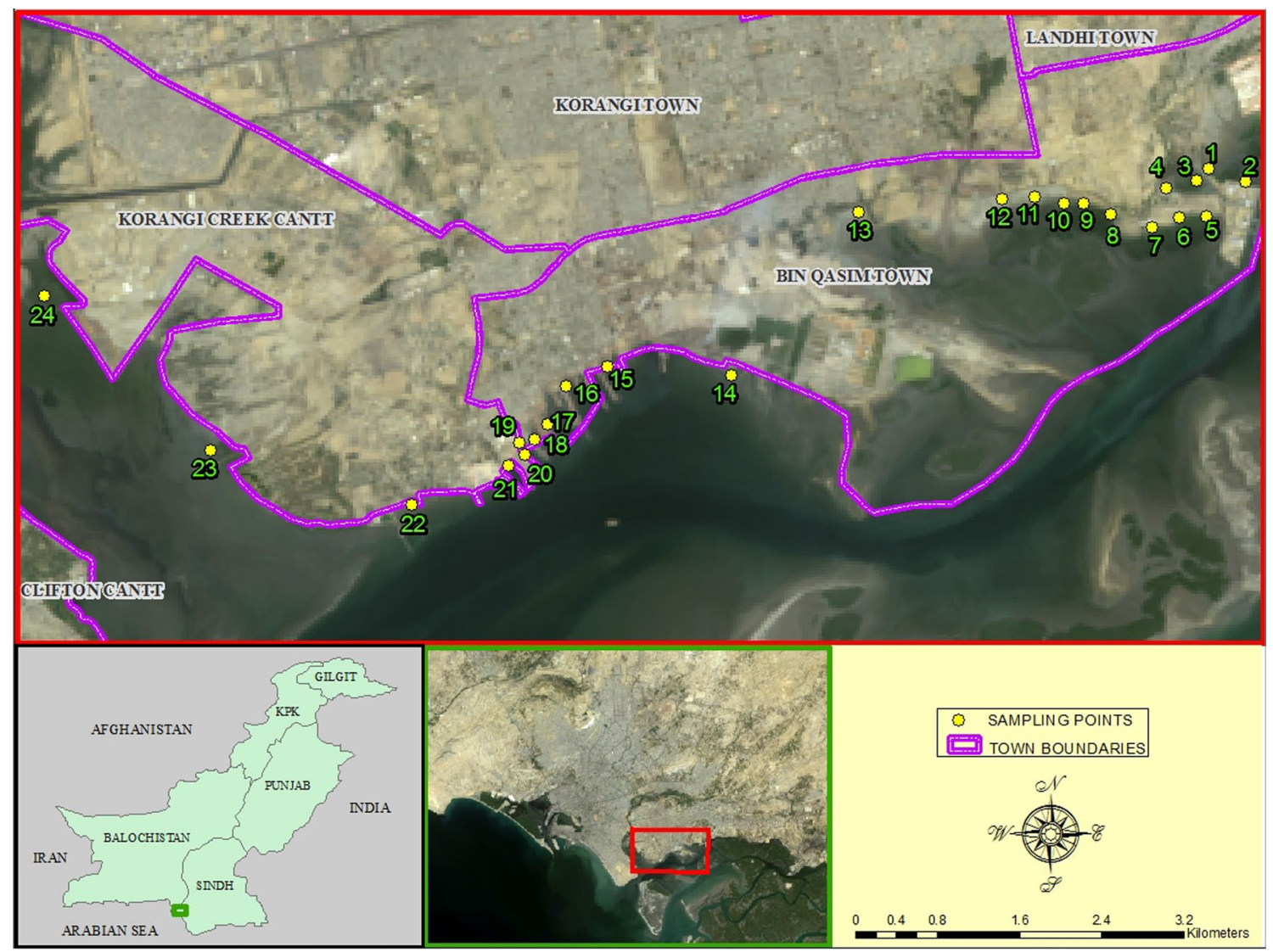

Fig. 1 Sampling points of Korangi creek

The above-mentioned characteristics were analyzed as per methods described in APHA (2005). NOVA-60 (Merck spectroquant) was used for the analysis of heavy metals in water and sediment samples.

\section{Collection and processing of sample for benthic communities}

Benthic sample was obtained using Patterson grab from the designated sampling locations. At each site, a quadrat of $1.0 \mathrm{~m}^{2}$ was placed at random and the sediment along with benthic organisms and was collected and transferred in the plastic bags. Formalin (10\%) was added to the sample to ensure adequate fixing of all the material. Rose Bengal (1\% solution in $\mathrm{D} / \mathrm{W}$ ) was also added to the sample so as to stain the benthic organisms, which made sorting much easier.

\section{Sieving and sorting}

In laboratory, each plastic bag containing biotic sample was carefully opened and the contents were transferred on a sieve of $0.5 \mathrm{~mm}$ mesh. The bottom of the sieve was gently dipped several times in water stored in sink. The remaining sediment on the sieve was transferred to Petri plates, and the benthic organisms were handpicked, mostly under a stereomicroscope. Care was taken to pick up all the organisms present in the sediment sample. These organisms were put in suitable containers, and fresh formalin solution (10\%) was added. The containers were properly labeled.

\section{Diversity analysis}

The general diversity $(H)$ was estimated using the information theory function, as follows:

$H=-\sum p_{i} \ln p_{i} \quad i=1, \ldots, S$

where $p_{i}$ the proportion of $i$ th taxon (organisms were classified into major taxa and not identified to species level), and $S$ equals the number of taxa. The components of diversity, namely equitability $(J)$ (Magurran 2004) and species (taxon) richness $(d)$ were measured as follows:

$J=\frac{H_{\text {obs }}}{H_{\max }}$ 
where $H_{\mathrm{obs}}$ equals the observed general diversity and $H_{\max }$ equals the maximal diversity.

$d=\frac{S}{\sqrt{N}}$

where $S$ equivalents to the number of taxa while $N$ equivalents to the total count.

\section{Statistical analysis}

STATISTICA (99 Edition) software was used for statistical investigation. Descriptive statistics was computed for each variable. The eigenvalues and eigenvectors were extracted from the original variables through PCA (principal component analysis). Cluster investigation was accomplished by Wards method. The function of Cluster analysis is to group the objects based on their similar or common characteristics.
Table 1 Descriptive statistics of physical, chemical and microbiological parameters of Korangi creek water
Table 2 Descriptive statistics of physical, chemical parameters of sediments of Korangi Creek

\begin{tabular}{lrllllllr}
\hline Variable $(\mathrm{mg} / \mathrm{l})$ & Mean & Median & Min. & Max. & $\begin{array}{l}\text { Lower } \\
\text { quartile }\end{array}$ & $\begin{array}{l}\text { Upper } \\
\text { quartile }\end{array}$ & SD & Std. error \\
\hline pH & 7.41 & 7.40 & 7.10 & 7.70 & 7.30 & 7.50 & 0.15 & 0.03 \\
Salinity $(\% o)$ & 36.00 & 36.41 & 29.22 & 38.62 & 35.36 & 37.28 & 2.07 & 0.42 \\
BOD $_{5}$ & 287.96 & 295.00 & 151.00 & 353.00 & 251.00 & 342.50 & 58.41 & 11.92 \\
COD & 1231.9 & 1215 & 998 & 1498 & 1183 & 1300 & 114.2 & 23.31 \\
Chlorophyll $(\mu \mathrm{g} / \mathrm{l})$ & 2.64 & 2.32 & 2.08 & 4.25 & 2.13 & 2.86 & 0.67 & 0.14 \\
Cyanide & 0.13 & 0.12 & 0.12 & 0.23 & 0.12 & 0.13 & 0.02 & 0.00 \\
DO & 4.55 & 4.45 & 3.30 & 5.30 & 4.35 & 5.10 & 0.53 & 0.11 \\
Oil and grease & 9.56 & 9.46 & 6.24 & 12.69 & 8.35 & 10.78 & 1.60 & 0.33 \\
Phenol & 0.61 & 0.63 & 0.33 & 0.82 & 0.52 & 0.73 & 0.12 & 0.03 \\
Phosphate & 2.57 & 2.65 & 0.68 & 4.54 & 1.87 & 3.38 & 0.98 & 0.20 \\
TKN & 73.47 & 73.30 & 63.33 & 78.90 & 71.32 & 76.21 & 3.60 & 0.74 \\
As & 0.15 & 0.15 & 0.12 & 0.18 & 0.14 & 0.16 & 0.01 & 0.00 \\
Cr & 0.59 & 0.61 & 0.42 & 0.73 & 0.52 & 0.62 & 0.08 & 0.02 \\
Cu & 3.31 & 3.53 & 1.52 & 6.54 & 2.11 & 4.52 & 1.31 & 0.27 \\
Pb & 5.49 & 5.50 & 3.41 & 7.62 & 5.03 & 6.09 & 0.97 & 0.20 \\
$\mathrm{Ni}$ & 2.10 & 2.32 & 1.22 & 2.89 & 1.63 & 2.45 & 0.51 & 0.10 \\
$\mathrm{Zn}$ & 1.71 & 1.69 & 1.42 & 2.49 & 1.57 & 1.81 & 0.22 & 0.04 \\
TCC MPN/100 ml & 1188.7 & 780 & 75 & 2400 & 157.5 & 2400 & 200 & 1103.5 \\
TFC MPN/100 ml & 147.25 & 75 & 21 & 460 & 40 & 240 & 0 & 135.76 \\
\hline
\end{tabular}

\begin{tabular}{llllllrrr}
\hline Variable $(\mathrm{mg} / \mathrm{kg})$ & Mean & Median & Min. & Max. & Lower quartile & Upper quartile & SD & Std error \\
\hline $\mathrm{pH}$ & 7.51 & 7.50 & 7.40 & 7.80 & 7.45 & 7.55 & 0.10 & 0.02 \\
$\mathrm{BOD}_{5}$ & 1645.3 & 1643 & 1328 & 1898 & 1556 & 1754.00 & 139.15 & 28.40 \\
$\mathrm{COD}$ & 4725 & 5142 & 3189 & 6015 & 4027.5 & 5282.50 & 856.55 & 174.84 \\
Cyanide & 3.53 & 3.54 & 2.21 & 5.29 & 3.12 & 4.22 & 0.88 & 0.18 \\
Oil and grease & 51.77 & 54.35 & 16.84 & 71.88 & 44.33 & 63.72 & 15.26 & 3.11 \\
Phenol & 8.11 & 8.27 & 5.72 & 9.72 & 7.37 & 8.84 & 1.08 & 0.22 \\
Phosphate & 9.78 & 9.07 & 6.87 & 14.54 & 8.49 & 10.33 & 2.15 & 0.44 \\
$\mathrm{TKN}$ & 146.22 & 147.69 & 122.32 & 176.21 & 136.00 & 156.42 & 14.26 & 2.91 \\
$\mathrm{As}$ & 5.49 & 1.27 & 1.12 & 100.00 & 1.24 & 1.43 & 20.13 & 4.11 \\
$\mathrm{Cr}$ & 2.45 & 2.47 & 1.21 & 4.26 & 1.84 & 2.82 & 0.73 & 0.15 \\
$\mathrm{Cu}$ & 2.99 & 2.88 & 2.19 & 4.76 & 2.58 & 3.29 & 0.61 & 0.12 \\
$\mathrm{~Pb}$ & 6.73 & 6.62 & 5.68 & 10.55 & 6.26 & 7.02 & 0.95 & 0.19 \\
$\mathrm{Ni}$ & 4.25 & 4.26 & 2.12 & 6.25 & 3.93 & 4.68 & 0.81 & 0.17 \\
$\mathrm{Zn}$ & 2.74 & 2.74 & 1.59 & 5.23 & 2.13 & 3.23 & 0.78 & 0.16 \\
\hline
\end{tabular}




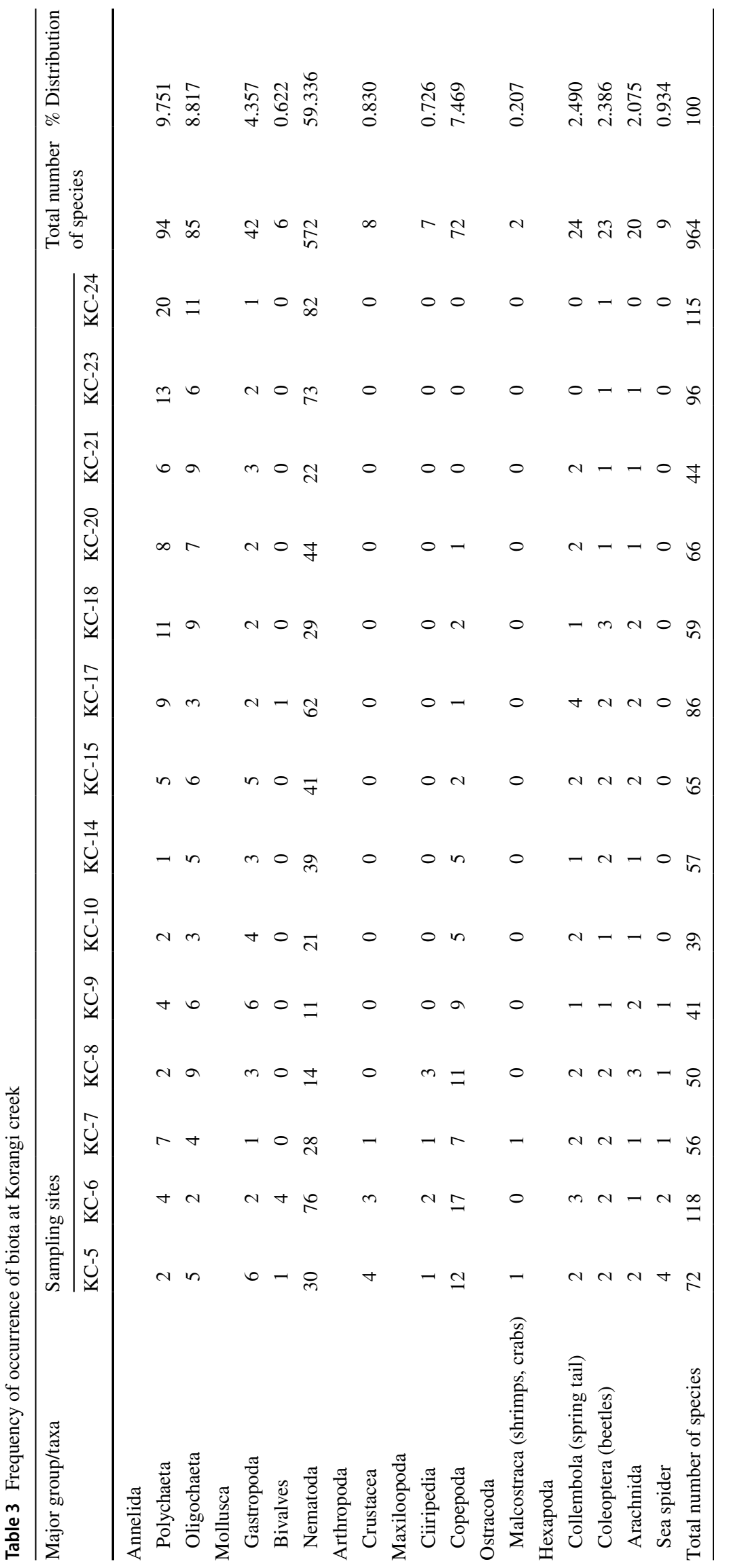




\section{Result and discussion}

The pollution profile of Korangi creek was assessed through physical, chemical and microbiological parameters. During present investigation, biota samples were also collected from benthic deposits from 14 sampling sites. Tables 1 and 2 present descriptive statistics of physical, chemical and microbiological parameters of water and sediments of Korangi creek. To date, no previous data are available pertaining to quality of seawater and sediments to compare with. The frequency of occurrence of biota is reported in Table 3.

The average $\mathrm{pH}$ of seawater and the sediment is 7.41 and 7.51 , respectively. In general, the trend of $\mathrm{pH}$ of both the water and sediment is neutral; therefore, presumably, it could hardly bring about major changes in the marine ecosystem of the Korangi creek. Mean salinity of seawater is $36 \%$ that fluctuated in a wide range of $29.22-38.62 \%$. This is increment with the values previously reported (Khatoon and Hussain 2006; Yousuf and Wasee 2006).

The organic pollution load in water bodies is generally established through BOD5, COD and TOC (total organic carbon). BOD5 and COD indicate the organic and inorganic pollution load of wastewater (Luz and Barkan 2000). COD test is, however, considered superior to BOD because it is less time-consuming and simple (Kim et al. 2001).

The mean $\mathrm{BOD}_{5}$ value of seawater is $288 \mathrm{mg} / \mathrm{l}$ while that of the sediments is $1645 \mathrm{mg} / \mathrm{kg}$. Elevated BOD level suggested the high organic load in creek water that is possibly due to increased suspended solids of biological source. These suspended solids may be attributed to silt, decomposing biological material that contributes to turbidity. The BOD levels of seawater were relatively higher at KC-15 to KC-21. These sites are located at Ibrahim Haidry jetty. These sites also receive untreated wastewater mainly of domestic origin from the nearby settlements. The maximum BOD value $(353 \mathrm{mg} / \mathrm{l})$ was found at $\mathrm{KC}-24$, which represents Malir river outfall. Khan et al. (2012) also reported similar BOD values of Gizri creek area which is adjacent to Korangi creek. Similar BOD profile was also observed in Chinna, Rehri and Gharo creek areas. All these creeks are situated in Greater Karachi and are continuously receiving untreated domestic discharges throughout the year (Khan et al. 2004; Shahzad et al. 2009; Khan et al. 2012). Malir river, in fact, carries untreated wastewater of both domestic and industrial origin from the eastern part of Karachi city. The minimum BOD value of sediment was at KC-1 $(1328 \mathrm{mg} / \mathrm{kg})$ that represents the site at Korangi fish harbor. The maximum BOD value was found at $\mathrm{KC}-13(1898 \mathrm{mg} / \mathrm{kg})$ that received domestic wastewater from Korangi residential area. Anthropogenic sources around the study area are responsible for high BOD concentration. Elevated BOD concentration at the sampling sites near fishing communities is also due to throwing away of spoiled fishes by the indigenous communities which undergo the process of putrefaction and thus increase organic load. Dissolved oxygen concentration tends to reduce due to elevated BOD level as the oxygen is consumed by microorganisms creating oxygen deficient environment which is harmful to marine life.

COD concentration at the creek area also showed analogous trend to that of BOD. High COD values were noticed at the sampling locations close to the human settlements (KC-11, KC-17, KC-1, and KC-20). Average COD concentration of the sampling sites was $1231.9 \mathrm{mg} / \mathrm{l}$. The highest COD value was observed at KC-24 (1498 mg/l). There is no apparent linear relationship between BOD and COD in relatively clean seawater samples away from the shoreline (Jin et al. 2009). However, in estuary having relatively high concentration of sewage contamination, a linear correlation does exist between BOD and COD. In the present study, there are numerous sources of industrial effluent, which ultimately find its way at Korangi creek. Moreover, untreated domestic effluent from the nearby communities also dumped into the creek area. This high volume of untreated domestic and industrial discharges is badly affecting the creek ecosystem. The high COD values of the sediments also indicate continuous accumulation of toxic chemicals. The maximum COD value of sediment is at $\mathrm{KC}-13(6015 \mathrm{mg} / \mathrm{kg})$ while minimum value was $3189 \mathrm{mg} / \mathrm{kg}$ at $\mathrm{KC}-2$.

The planktonic or benthic microalgae, macrophytes and epiphytic micro-flora are responsible for maintaining the dynamicity of the marine ecosystem (Barnes 1980; Conde et al. 1999). Chlorophyll a, b and c represents important floral components of an aquatic ecosystem. However, chlorophyll $\mathrm{a}$ is the most important fraction which is used to determine the algal biomass. Chlorophyll "a" concentration of the sampling sites is presented in Table 1. The mean chlorophyll value was $2.64 \mu \mathrm{g} / \mathrm{l}$. The highest value of chlorophyll was at KC-3 (4.25 $\mu \mathrm{g} / \mathrm{l})$ which presumably represents a high number of small concrete mangrove communities in the area. The higher levels of chlorophyll represent the greater primary productivity of the creek area.

The use of cyanide is a common practice in many parts of the world for fishing. No adverse effects have been noted regarding the sublethal dose of cyanide until 1-2 weeks after fish catching (Rubec 1986). Acute human toxicity of cyanide at a concentration of $0.1-0.3 \mathrm{mg} / \mathrm{l}$ may cause death within $96 \mathrm{~h}$ (Doudoroff 1980). However, it is reported that the cyanide concentration between 0.005 and $0.01 \mathrm{mg} / \mathrm{l}$ show evidence of adverse effect on fishes. These affects include abridged growth, depressed swimming performance, reproduction impairment and enhanced respiratory rates (Leduc 1984). This might be primarily due to blocking of cytochrome oxidase system as cyanide interferes with respiratory chain. (Alazemi et al. 1996) reported that cyanide in concentration of $0.05 \mathrm{mg} / \mathrm{l}$ caused epithelial 
system disruption of freshwater fish Gnathonemus petersii. As reported by some workers such as Rubec and Pratt (1984), very little scientific research has been published on the effects of cyanide on marine fishes. The average cyanide concentration of seawater and sediment in Korangi creek is $0.13 \mathrm{mg} / \mathrm{l}$ and $3.53 \mathrm{mg} / \mathrm{kg}$, respectively. The concentration of cyanide in sediments is exceptionally higher. This is mainly due to the heavy discharges into the creek area from Korangi industrial estate. Cyanide is widely used in electroplating, metal refining, organic chemical production and many other processes (Nagaraja et al. 2002). These industries are located both in formal and informal sectors of Korangi industrial estate. Cyanide forms complex compounds which are often less toxic compared to free cyanide (Fuller and Randle 1984).

The mean dissolved oxygen concentration of seawater in Korangi creek area was $4.55 \mathrm{mg} / \mathrm{l}$. The DO level of the creek area ranged between 3.30 (KC-1) to $5.30 \mathrm{mg} / \mathrm{l}(\mathrm{KC}-20$ and $\mathrm{KC}-22)$. It can be argued that this level of DO concentration might be due to high BOD concentration, which indicates the extent of oxygen stress on the creek ecology (Dhage et al. 2006). The aerobic and anaerobic mineralization on water and sediment crossing point wear out oxygen and revitalize nutrients (Jørgensen 1983). Wildish et al. (1993) suggested the important process control the levels of dissolved oxygen in seawater are the movement of oxygen-saturated water that removes dissolved oxygen deficits water, photosynthetic oxygen production which supersaturates seawater with dissolved oxygen during the spring and summer and chemical and biological oxidation processes which could be dominant in removing dissolved oxygen during the night and in the late summer/fall when temperatures remain high but photosynthetic activity is low. (Allan et al. 1990) reported that reduced DO levels significantly increased the acute toxicity of ammonia to leader prawns (Penaeus monodon). In general, DO was higher $(>5.0 \mathrm{mg} / \mathrm{l})$ from sites $\mathrm{KC}-18$ to $\mathrm{KC}-23$, whereas in rest of the sites, it remained less than $5.0 \mathrm{mg} / \mathrm{l}$. Remarkably, not all sites are facing anoxic state which generally exists when the level of DO is less than $2.0 \mathrm{mg} / \mathrm{l}$ (Diaz and Rosenberg 1995). In estuaries and adjacent coastal waters, the DO level is less than $4.0 \mathrm{mg} / \mathrm{l}$ that normally found in summer (Yin et al. 2004).

Marine water quality largely depreciates due to oil pollution (Abdullah et al. 1996) as dispersed oil amplified the toxicity which is harmful to marine biota (Anderson et al. 2009; Bartoli et al. 2001). Oil itself is less polluted as compared to the chemical components that are present in different types of oil of which petroleum hydrocarbons are most potent that occurs together in gaseous and liquid state. The accumulation of considerable amount of petroleum compounds may cause immediate increment in $\mathrm{BOD}_{5}$ to any water body because of hydrocarbon degraders activities that hamper oxygen dissolution. Oil and grease are known to block the assimilation of ambient oxygen in the water thereby produce suffocation toxic to marine life forms. Fishing activities and navigation operations in sea are the main contributor of oil and grease that undergo instantaneous degradation by aquatic bacteria particularly in oxygenated environment. However, oil and grease also have a tendency to descend in the bottom and keep on deposit where it subject to relatively slow microbial degradation due to low dissolved oxygen concentration. Oil and grease in seawater ranged between 6.24 and $12.69 \mathrm{mg} / \mathrm{l}$, while that of sediments ranged between 16.84 and $71.88 \mathrm{mg} / \mathrm{kg}$. The highest oil and grease value in seawater was at KC-23 and KC-24. These are the sites close to the Malir River outfall. The highest sediment value was observed at KC-20 and KC-24, which are close to the outfall. Comparatively elevated amount of oil and grease have been estimated for creek water of Indus delta (Khan and Shaukat 2008). It can be seen from Tables 1 and 2 that the sediments contained much higher amount of oil. This would mean that the normal system of removal of oil through the process of photooxidation, sedimentation and biodegradation is not working effectively at the bottom because of anoxic condition. Oil biodegradation rates are however difficult to predict due to the complexity of the environment, while rates of biodegradation are also dependent on the characteristics of oil (Zahed et al. 2010).

The growth, survival, metabolism and reproductive system of fish are affected once phenols enter in the fish body (Holmberg et al. 1972; Verma et al. 1980; Mukherjee et al. 1991). However, the literature about the phenol toxicity at the level of ecosystem is only scanty (Saha et al. 1999; Hwang et al. 1986). Photolysis is the most important transformation process for the polychlorinated phenols. They further suggested that microbial degradation and winter photolysis rates are lesser than those of summer. Eklund and Kautsky (2003) described that macro-algae are more susceptible to phenol than other aquatic life forms. The mean levels of phenol in seawater were $0.61 \mathrm{mg} / \mathrm{l}$ while that of the sediment was $8.11 \mathrm{mg} / \mathrm{kg}$. The highest value of phenol concentration $(0.82 \mathrm{mg} / \mathrm{l})$ was observed at $\mathrm{KC}-24$ while in sediment it was at $\mathrm{KC}-17(9.72 \mathrm{mg} / \mathrm{kg})$. Phenol is often considered as one of the major component of industrial wastewater particularly that of chemical industry. In addition, phenol is also present in appreciable quantity in the discharges of metal industry, pharmaceutical, paint and varnish industries, textile industries, etc., (Navarro et al. 2008). It is evident from the phenol concentration in seawater and the sediment that the elevated concentrations of phenol are mainly due to the untreated discharges of industrial origin from the Korangi industrial area. In the industrial estate, a large number of tanneries are also located where phenol is one of the constituent in their effluents. Phenol is detrimental to marine life even at concentration as low as $5 \mu \mathrm{g} / \mathrm{l}$ (Navarro et al. 2008). 
The macrophytes and benthic microalgae as well as macrophytes are responsible for maintaining the primary productivity in seawater. The nutrient progression can support and maintain phytoplankton blooms and macro-algal growth (Bartoli et al. 2001). Increased primary productivity can be linked with high nutrients input (Castel et al. 1996). Dissolved inorganic phosphate primarily presents in orthophosphoric acid form in the sea. The average concentration is $73 \mu \mathrm{g} / \mathrm{l}$ of dissolved orthophosphate in sea (Martin 1972) while (Boto 1982) is of the opinion that if the concentration is $31 \mu \mathrm{g} / \mathrm{l}$ it would be considered as low. The mean phosphorus concentration in seawater was $2.57 \mathrm{mg} / \mathrm{l}(0.68-4.54 \mathrm{mg} / \mathrm{l})$ while that of sediment was $9.78 \mathrm{mg} / \mathrm{kg}(6.87-14.54 \mathrm{mg} / \mathrm{kg}$.). The input of phosphate is mainly from nearby anthropogenic sources. The area near the outfall exhibited the highest concentration of phosphate both in water and in the sediments (KC-24). Vazquez et al. (2000) reported $18 \mu \mathrm{g} / \mathrm{l}$ concentrations of phosphates from mangrove areas, which is quite low compared to the present study. The system of phosphorus flow between water and is a multifaceted process that is controlled by physical, chemical and biological course of action which in turn dependent on seawater temperature, $\mathrm{pH}$ and redox potential (Carlton and Wetzel 1988). It has also been reported that in the Mediterranean coastal lagoons the major problem is an excessive input of nutrients (i.e., $\mathrm{N}$ and $\mathrm{P})$ causing eutrophication in summer. The sediments of these lagoons can serve as a reservoir or as a source of phosphate (Mesnage and Picot 1995).

Nitrogen is the nutrient that potentially retards phytoplankton production in temperate marine systems (Caraco et al. 1987; Howarth 1988). In shallow coastal lagoons, the predominant form of inorganic nitrogen is ammonium (Serpa et al. 2007). In sediments, there is lesser diffusion of oxygen that primarily reduces rate of nitrification consequently there is low concentrations of nitrates in the sediments. In the present study, the emphasis was on the available nitrogen in the form of TKN. The mean TKN of seawater was $73.47 \mathrm{mg} / \mathrm{l}$ while that of sediment was $146.22 \mathrm{mg} / \mathrm{kg}$. The TKN concentration was exceptionally higher in all sediment samples. This could also be attributed to flushing of organic matter that originates from anthropogenic sources. Another possible source of TKN could be the disposal of dead fishes in the creek from the fishing communities. In general, both $\mathrm{N}$ and $\mathrm{P}$ are responsible for increased primary productivity of the creek area.

The mean values of all the metals of seawater and sediments are presented in Tables 1 and 2. In all seawater and sediment samples, the concentration of $\mathrm{Pb}$ was highest and the mean values of $\mathrm{Pb}$ were $5.49 \mathrm{mg} / \mathrm{l}$ and $6.73 \mathrm{mg} / \mathrm{kg}$, respectively. The availability of high concentration of $\mathrm{Pb}$ in both water and sediment samples could be mainly due to the fuel used for operating the fishing vessels. The fishing vessels in the area are mostly operated through petrol or diesel. These defective boats render the spillage of fuel, which is a common problem in the area. The amount of other heavy metals in the seawater was established to be in the order $\mathrm{Cu}>\mathrm{Cr}>\mathrm{Ni}>\mathrm{Zn}>\mathrm{As}$. The trend in sediment was slightly different and followed the following pattern As $>\mathrm{Ni}>\mathrm{Cu}>\mathrm{Cr}>\mathrm{Zn}$. As expected, the concentration of metals in all the sediment samples was higher compared to that of seawater. It was reported that copper, zinc and lead are normal constituents of marine and estuarine environments (Bryan 1971). The additional quantities are introduced from industrial wastes or sewage. When they enter in the biogeochemical cycle, they become potentially toxic and detrimental to marine organisms. Apparently, the sources of these metals are mainly the untreated industrial discharges. The highest concentration of all the metals was found at $\mathrm{KC}-24$. The concentrations of heavy metals in seawater are mainly influenced by biological uptake (Moore 1978), release as of bottom sediments, mingling of water masses and transport of land-dwelling materials (Jones and Murray 1984; Wangersky 1986) $\mathrm{Cu}$ and $\mathrm{Pb}$ varied with the concentration of nutrients and exhibit marked seasonality. Copper, however, is the most commonly tested metal followed by zinc, cadmium, mercury, and lead in order of number of test results (Eklund and Kautsky 2003). Sediments with analogous mineral characteristics have same capacities to accrue metals from adjoining environments. However, with dissimilar mineral composition, sediments will accrue metals with varied sorptive capabilities (Esslemont 2000). Nonetheless, under field conditions, examples of deleterious effects on benthic organisms that can be attributed to specific metallic pollutants are comparatively rare (Bryan and Langston 1992). Relatively higher concentration of Fe is presumably due to the untreated industrial wastewater. The health risks associated with these metals are also of great concern and noticed by many workers (Eriyamremu et al. 2005; Muchuweti et al. 2006).

Principal component analysis of seawater and sediments samples of Korangi creek is presented in Tables 4 and 5 and Figs. 2 and 3. The first three components of seawater (Table 4) explained $54.23 \%$ of the cumulative variance. The first principal component that accounted for $23.44 \%$ of total variance is governed by oil and grease, $\mathrm{Cu}, \mathrm{Pb}, \mathrm{TKN}$ and phenol. The second component that explained $16.15 \%$ variance is controlled by $\mathrm{pH}$, salinity, phosphate, $\mathrm{Zn}$ and TKN, while the third component that exhibited $14.63 \%$ of variance is attributed to $\mathrm{Ni}$, oil and grease, phenol, BOD5 and chlorophyll. The results of PCA of sediments explained $66.09 \%$ of cumulative variance (Table 5). The first component showed $36.79 \%$ of the total variance is controlled by oil and grease, $\mathrm{Zn}, \mathrm{CN}$, BOD5 and $\mathrm{Cr}$. The second component exhibited $16.61 \%$ variance is a function of $\mathrm{Ni}, \mathrm{Pb}, \mathrm{COD}$, phenol and phosphate. The third component represented 
Table 4 Results of PCA of physical, chemical and microbiological parameters of Korangi creek water

\begin{tabular}{|c|c|c|c|c|c|}
\hline Component & Eigenvalue & $\begin{array}{l}\text { Percentage } \\
\text { variance }\end{array}$ & $\begin{array}{l}\text { Cumulative per- } \\
\text { centage variance }\end{array}$ & $\begin{array}{l}\text { First three eigen- } \\
\text { vector coefficients }\end{array}$ & Associated variables \\
\hline 1 & 3.9852 & 23.44 & 23.44 & $\begin{array}{r}-0.7737 \\
-0.7562 \\
-0.7119 \\
0.5908 \\
-0.5690\end{array}$ & $\begin{array}{l}\text { Oil and grease } \\
\mathrm{Cu} \\
\mathrm{Pb} \\
\mathrm{TKN} \\
\text { Phenol }\end{array}$ \\
\hline 2 & 2.7461 & 16.15 & 39.59 & $\begin{array}{r}0.7819 \\
0.7402 \\
-0.6904 \\
-0.6258 \\
0.5510\end{array}$ & $\begin{array}{l}\mathrm{pH} \\
\text { Salinity } \\
\text { Phosphate } \\
\text { Zn } \\
\text { TKN }\end{array}$ \\
\hline 3 & 2.4879 & 14.63 & 54.23 & $\begin{array}{r}-0.8143 \\
0.5720 \\
-0.5461 \\
-0.5130 \\
-0.5032\end{array}$ & $\begin{array}{l}\mathrm{Ni} \\
\text { Oil and grease } \\
\text { Phenol } \\
\mathrm{BOD}_{5} \\
\text { Chlorophyll }\end{array}$ \\
\hline
\end{tabular}

\begin{tabular}{|c|c|c|c|c|c|}
\hline Component & Eigenvalue & $\begin{array}{l}\text { Percentage } \\
\text { variance }\end{array}$ & $\begin{array}{l}\text { Cumulative per- } \\
\text { centage variance }\end{array}$ & $\begin{array}{l}\text { First three eigen- } \\
\text { vector coefficients }\end{array}$ & Associated variables \\
\hline 1 & 5.1513 & 36.79 & 36.79 & $\begin{array}{r}0.8999 \\
0.8957 \\
0.8621 \\
0.7145 \\
-0.6750\end{array}$ & $\begin{array}{l}\text { Oil and grease } \\
\mathrm{Zn} \\
\mathrm{CN} \\
\mathrm{BOD}_{5} \\
\mathrm{Cr}\end{array}$ \\
\hline 2 & 2.3252 & 16.61 & 53.40 & $\begin{array}{r}0.6690 \\
0.6396 \\
-0.5760 \\
-0.4728 \\
0.4612\end{array}$ & $\begin{array}{l}\mathrm{Ni} \\
\mathrm{Pb} \\
\mathrm{COD} \\
\text { Phenol } \\
\text { Phosphate }\end{array}$ \\
\hline 3 & 1.7762 & 12.68 & 66.09 & $\begin{array}{r}-0.7236 \\
-0.5025 \\
-0.4986 \\
-0.4459 \\
0.4066\end{array}$ & $\begin{array}{l}\mathrm{As} \\
\mathrm{Cu} \\
\text { Phenol } \\
\text { TKN } \\
\text { Phosphate }\end{array}$ \\
\hline
\end{tabular}

Table 5 Results of PCA of physical and chemical parameters of Korangi Creek Sediment subdivided into two subgroups which are $2 \mathrm{~A}$ and $2 \mathrm{~B}$. Sites of $2 \mathrm{~A}$ had moderate values of all the parameters. Group 2B further subdivided into two 2B1, 2B2 and 2B3. All these sites have lower values of all the parameters as compared to Group 1. No significant difference was observed with regard to chlorophyll, cyanide and DO among the subgroups of Group 2.

Figure 4 shows the dendrogram derived from the data on physical, chemical and microbial properties of water samples of Korangi creek. Two main groups can be seen in the phenol and phosphate compared to other sites. Group 2 was 


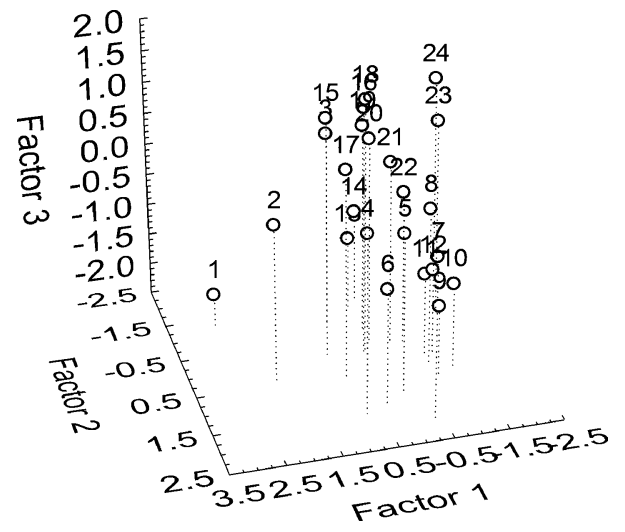

Fig. 2 Principal component analysis ordination (3D) of physical, chemical and microbiological parameters of Korangi creek water

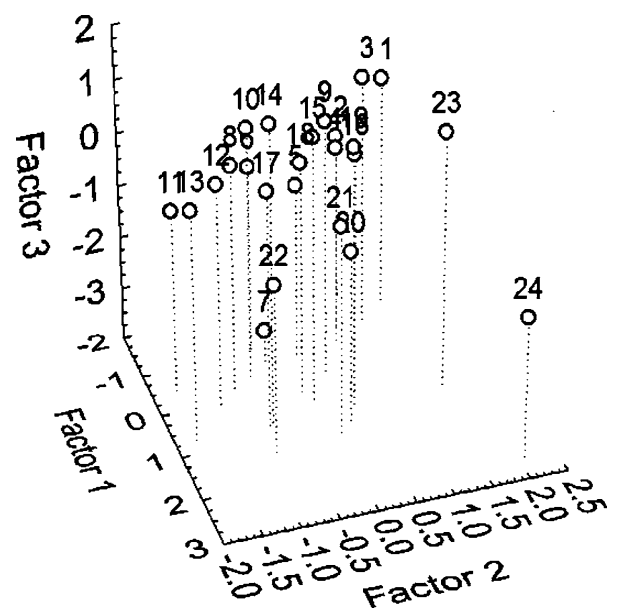

Fig. 3 Principal component analysis ordination (3D) of physical and chemical parameters of Korangi creek sediment

dendrogram. Group 1 comprises of 10 samples that have generally high BOD, low chlorophyll content, greater phenol and phosphate but low in TKN and $\mathrm{pH}$. Group 2 is characterized by relatively low BOD and phenol but relatively greater salinity and chlorophyll. The subgroups $2 \mathrm{~A}$ and $2 \mathrm{~B}$ are distinguished by low BOD and COD of group $2 \mathrm{~A}$ while higher BOD and COD of group 2B.

Figure 4 presents the dendrogram based on physical and chemical characteristics of the sediments of Korangi creek. Two main groups emerged in the dendrogram. Group 1 consisting of 17 samples (sites) shows high BOD, COD, cyanide and phosphate, whereas Group 2 exhibits lower $\mathrm{pH}$, BOD and COD (Fig. 5).

Figure 6 shows the dendrogram based on 14 sampling sites of the benthic biota of Korangi creek. Again two major groups emerged in the dendrogram. Group 1 comprising of four samples is characterized by high frequency of Annelides and Nematodes but low frequency of Crustacea. On the other hand, group 2 which contains 10 samples shows low frequency of Annelida, Mollusca but slightly greater frequency of hexapoda.

Table 6 presents the general diversity $(H)$, equitability $(J)$, their variances, species richness $(d)$ and dominance $(D)$. Sites 5 and 8 had high general diversity $(H)$, while sites 23 and 24 showed low diversity. Sites 8 and 9 yielded high equitability $(J)$, while sites 23 and 17 showed low equitability. The sites with high general diversity $(H)$ and equitability $(J)$ in general have lower pollution levels, particularly of heavy metals. Species richness $(d)$ was high for sites 7 and 5, while low for sites 23 and 24. Sites 5 and 8 depicted low dominance $(D)$. Dominance and diversity are, in general, inversely related. A number of taxa were highest for site 5 and lowest for site 23 .

\section{Conclusions}

The study disclosed that the lagoon water is primarily polluted by organic load which originates from nearby human settlements. The concentration of oil and grease is exceptionally higher in water and sediment samples which is detrimental to marine life forms. The concentration of DO
Fig. 4 Dendrogram derived from Ward's method of 24 sites based on physical, chemical and microbiological quality of Korangi creek water

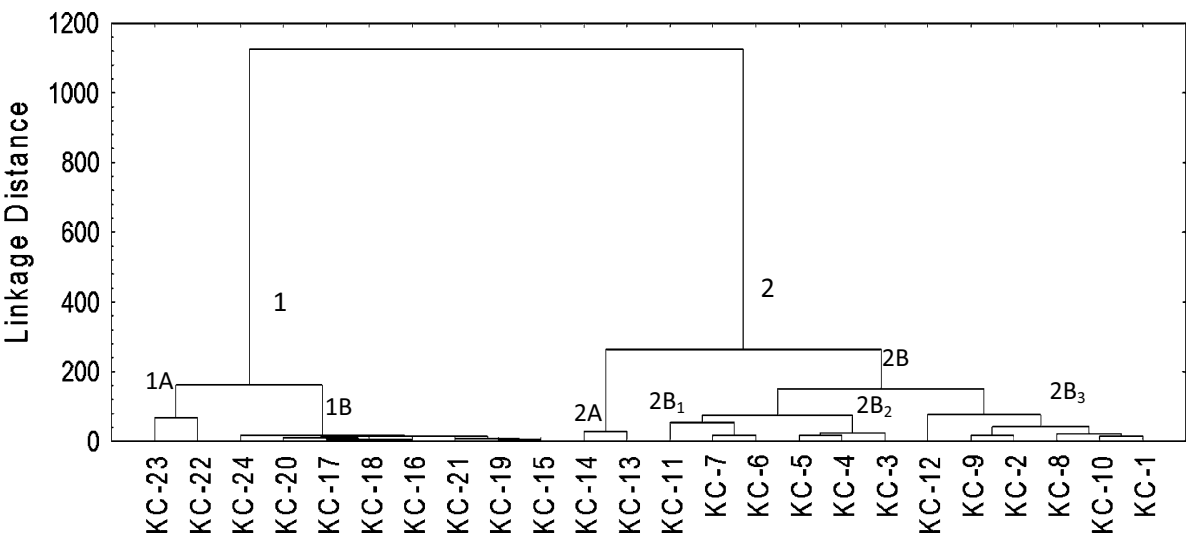


Fig. 5 Dendrogram derived from Ward's method of 24 sites based on physical and chemical quality of Korangi creek sediments

Fig. 6 Dendrogram derived from Ward's method of 14 sites based on benthic communities of Korangi creek

Table 6 General diversity $(H)$, equitability $(J)$, their variances, species richness $(d)$ and dominance $(D)$ of biota at Korangi creek
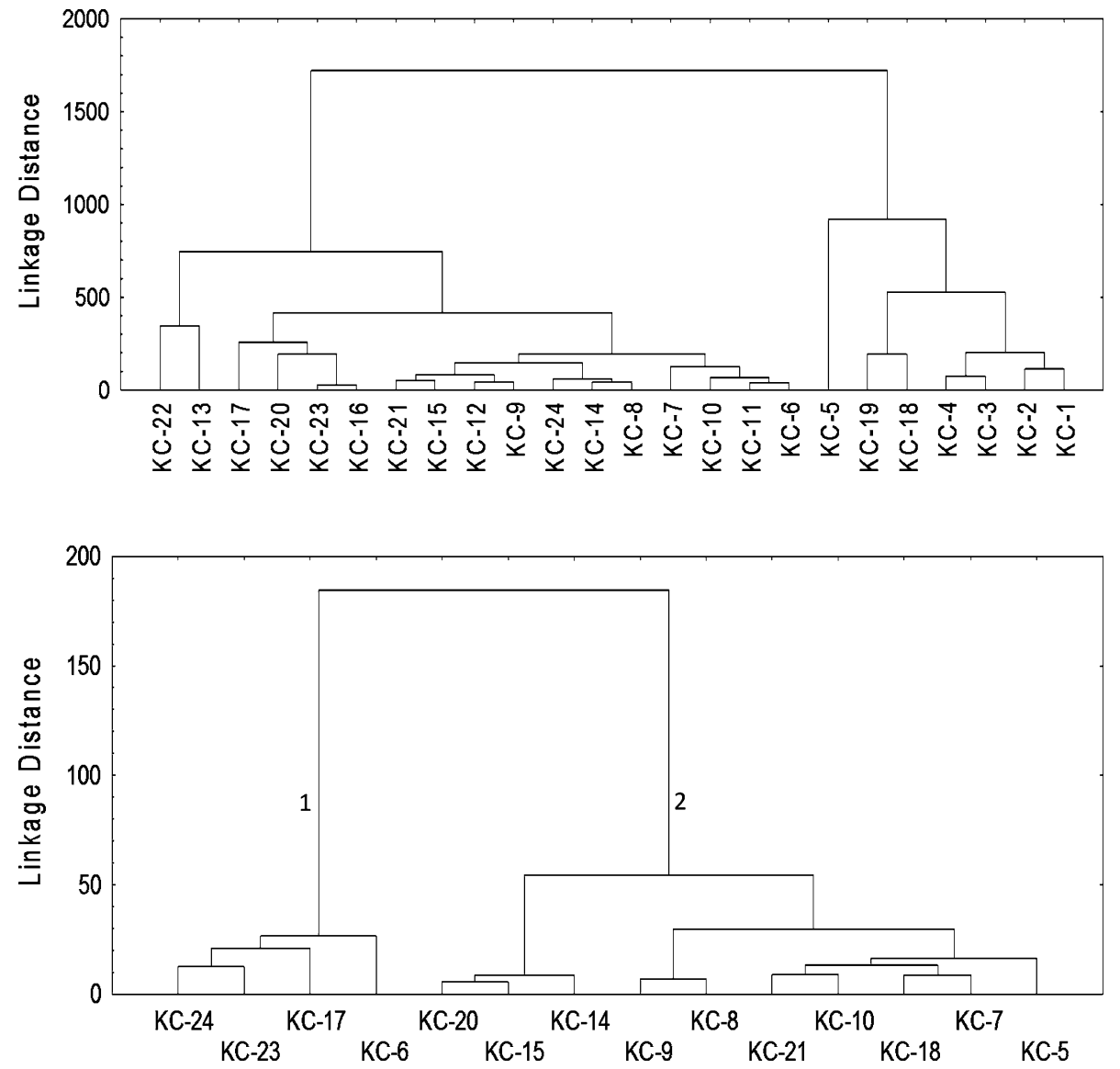

\begin{tabular}{llllllll}
\hline Sample code & $\begin{array}{l}\text { General } \\
\text { diversity } \\
(H)\end{array}$ & $\operatorname{Var}(H)$ & Equitability $(J)$ & Var $(J)$ & $\begin{array}{l}\text { Species } \\
\text { richness } \\
(d)\end{array}$ & Dominance $(D)$ & Taxa $(S)$ \\
\hline KC-5 & 1.953 & 0.017 & 0.761 & 0.002 & 1.532 & 0.212 & 13 \\
KC-6 & 1.364 & 0.016 & 0.549 & 0.002 & 1.104 & 0.436 & 12 \\
KC-7 & 1.724 & 0.026 & 0.693 & 0.004 & 1.603 & 0.277 & 12 \\
KC-8 & 1.969 & 0.013 & 0.855 & 0.002 & 1.414 & 0.158 & 10 \\
KC-9 & 1.894 & 0.013 & 0.862 & 0.002 & 1.405 & 0.156 & 9 \\
KC-10 & 1.520 & 0.029 & 0.731 & 0.006 & 1.281 & 0.311 & 8 \\
KC-14 & 1.171 & 0.026 & 0.563 & 0.006 & 1.059 & 0.479 & 8 \\
KC-15 & 1.333 & 0.022 & 0.641 & 0.005 & 0.992 & 0.412 & 8 \\
KC-17 & 1.097 & 0.020 & 0.499 & 0.004 & 0.970 & 0.530 & 9 \\
KC-18 & 1.513 & 0.016 & 0.728 & 0.003 & 1.041 & 0.293 & 8 \\
KC-20 & 1.166 & 0.021 & 0.560 & 0.005 & 0.984 & 0.464 & 8 \\
KC-21 & 1.438 & 0.019 & 0.739 & 0.005 & 1.055 & 0.302 & 7 \\
KC-23 & 0.828 & 0.012 & 0.462 & 0.003 & 1.612 & 0.596 & 6 \\
KC-24 & 0.852 & 0.007 & 0.529 & 0.002 & 0.466 & 0.544 & 5 \\
\hline
\end{tabular}


although not up to the mark but still be helpful for marine life. From the ecological perspective, the concentrations of phenol and cyanide were much higher in the sediment samples compared to seawater although no significant source of these pollutants was conceivable. TKN and phosphate were in greater concentrations in the samples collected from the mangrove areas. Out of six heavy metals tested, the concentration of $\mathrm{Pb}$ was exceptionally higher which is an indication of the leakage of fuel used in the defective motorboats. Principal component analysis and cluster analysis were found to be effective techniques to disclose the trends and group structure inherent in the data.

\section{Compliance with ethical standards}

Conflict of interest The authors declare that they have no conflict of interest. This article does not contain any study on the collected or captured animals.

Ethical approval All procedures performed in studies involving human participants were in accordance with the ethical standards of the institutional and/or national research committee and with the 1964 Helsinki Declaration and its later amendments.

Informed consent Informed consent was obtained from all individual participants of this study.

Open Access This article is distributed under the terms of the Creative Commons Attribution 4.0 International License (http://creativeco mmons.org/licenses/by/4.0/), which permits unrestricted use, distribution, and reproduction in any medium, provided you give appropriate credit to the original author(s) and the source, provide a link to the Creative Commons license, and indicate if changes were made.

\section{References}

Abdullah A, Woon W, Bakar R (1996) Distribution of oil and grease and petroleum hydrocarbons in the Straits of Johor, Peninsular Malaysia. Bull Environ Contam Toxicol 57(1):155-162

Alazemi B, Lewis J, Andrews E (1996) Gill damage in the freshwater fish Gnathonemus petersii (family: Mormyridae) exposed to selected pollutants: an ultrastructural study. Environ Technol 17(3):225-238

Allan GL, Maguire GB, Hopkins SJ (1990) Acute and chronic toxicity of ammonia to juvenile Metapenaeus macleayi and Penaeus monodon and the influence of low dissolved-oxygen levels. Aquaculture 91(3):265-280

Anderson BS, Arenella-Parkerson D, Phillips BM, Tjeerdema RS, Crane D (2009) Preliminary investigation of the effects of dispersed Prudhoe Bay crude oil on developing topsmelt embryos, Atherinops affinis. Environ Pollut 157(3):1058-1061

APHA (2005) Standard methods for the examination of water and wastewater, 21st edn. American Public Health Association, Washington DC, USA

Barnes RSK (1980) Coastal lagoons, vol 1. CUP Archive, Cambridge

Bartoli M, Nizzoli D, Viaroli P, Turolla E, Castaldelli G, Fano EA et al (2001) Impact of Tapes philippinarum farming on nutrient dynamics and benthic respiration in the Sacca di Goro. Hydrobiologia 455(1-3):203-212

Boto KK (1982) Nutrient and organic fluxes in mangroves. In: Mangrove ecosystems in Australia: structure, function and management. Australian National University Press, pp 239-258

Bryan G (1971) The effects of heavy metals (other than mercury) on marine and estuarine organisms. Proc R Soc Lond B Biol Sci 177(1048):389-410

Bryan G, Langston W (1992) Bioavailability, accumulation and effects of heavy metals in sediments with special reference to United Kingdom estuaries: a review. Environ Pollut 76(2):89-131

Caraco N, Tamse A, Boutros O, Valiela I (1987) Nutrient limitation of phytoplankton growth in brackish coastal ponds. Can J Fish Aquat Sci 44(2):473-476

Carlton RG, Wetzel RG (1988) Phosphorus flux from lake sediments: effect of epipelic algal oxygen production. Limnol Oceanogr 33(4):562-570

Castel J, Caumette P, Herbert R (1996) Eutrophication gradients in coastal lagoons as exemplified by the Bassin d'Arcachon and the Étang du Prévost. Hydrobiologia 329(1-3):ix-xxviii

Conde D, Bonilla S, Aubriot L, De León R, Pintos W (1999) Comparison of the areal amount of chlorophyll a of planktonic and attached microalgae in a shallow coastal lagoon. Hydrobiologia 408:285-291

Dhage S, Chandorkar A, Kumar R, Srivastava A, Gupta I (2006) Marine water quality assessment at Mumbai West Coast. Environ Int 32(2): 149-158

Diaz RJ, Rosenberg R (1995) Marine benthic hypoxia: a review of its ecological effects and the behavioural responses of benthic macrofauna. Oceanogr Mar Biol Annu Rev 33:245

Doudoroff P (1980) A critical review of recent literature on the toxicity of cyanides to fish. American Petroleum Institute

Eklund BT, Kautsky L (2003) Review on toxicity testing with marine macroalgae and the need for method standardization-exemplified with copper and phenol. Mar Pollut Bull 46(2):171-181

Eriyamremu G, Asagba S, Akpoborie I, Ojeaburu S (2005) Evaluation of lead and cadmium levels in some commonly consumed vegetables in the Niger-Delta oil area of Nigeria. Bull Environ Contam Toxicol 75(2):278-283

Esslemont G (2000) Heavy metals in seawater, marine sediments and corals from the Townsville section, Great Barrier Reef Marine Park, Queensland. Mar Chem 71(3):215-231

Fuller SJ, Randle PJ (1984) Reversible phosphorylation of pyruvate dehydrogenase in rat skeletal-muscle mitochondria. Effects of starvation and diabetes. Biochem J 219:635-646

Haq SM (1976) Overview of pollution in the coastal environment of Pakistan and its possible implication for the marine ecosystem. In: Proceedings of international symposium on marine pollution research, Gulf Breeze, Florida, Centre for Wetland Resources, Louisiana State University. Baton Rouge, L.A., USA pp 33-53

Holmberg B, Jensen S, Larsson Å, Lewander K, Olsson M (1972) Metabolic effects of technical pentachlorophenol (PCP) on the eel Anguilla anguilla L. Comp Biochem Physiol Part B Comp Biochem 43(1):171-183

Howarth RW (1988) Nutrient limitation of net primary production in marine ecosystems. Annu Rev Ecol Syst 19(1):89-110

Husain MS (1988) Navigation in Port Qasim. Defence Society, Karachi

Hwang HM, Hodson R, Lee R (1986) Degradation of phenol and chlorophenols by sunlight and microbes in estuarine water. Environ Sci Technol 20(10):1002-1007

IUCN (2005) Mangroves of Pakistan: status and management. International Union for Conservation of Nature. http://www.iucn.org

Jin X, Jing M, Chen X, Zhuang Z, Wang X, Lee F (2009) A study on the relationship between $\mathrm{BOD}_{5}$ and COD in coastal seawater 
environment with a rapid BOD measurement system. Water Sci Technol 61(6):1499-1503

Jones CJ, Murray JW (1984) Nickel, cadmium, and copper in the northeast Pacific off the coast of Washington 1, 2. Limnol Oceanogr 29(4):711-720

Jørgensen B (1983) Processes at the sediment-water interface. Major Biogeochem Cycles Interact 21:477-509

Khan MA, Shaukat SS (2008) Physico-chemical characteristics of water and sediments of Chinna creek and the associated benthic biota on its fringes. Int J Biol Biotechnol 5(1-2):133-141

Khan MA, Hany O, Hashmi I, Kazmi QB, Khan MA (2004) Pesticide pollution of Gharo Creek: a preliminary study. Pak J Mar Sci (Pak) 13(1\&2):11-14

Khan M, Zaheen W, Shaukat S (2012) Biodiversity in benthic communities of Chinna creek. FUUAST J Biol 2(2):19

Khatoon Z, Hussain S (2006) Some hydrographic features of KorangiPhitti Creek. Int J Biol Biotech 3:745-752

Kim Y-C, Sasaki S, Yano K, Ikebukuro K, Hashimoto K, Karube I (2001) Photocatalytic sensor for the determination of chemical oxygen demand using flow injection analysis. Anal Chim Acta 432(1):59-66

Leduc G (1984) Cyanides in water: toxicology significance. Aquat Toxicol Ser 2:153-224

Luz B, Barkan E (2000) Assessment of oceanic productivity with the triple-isotope composition of dissolved oxygen. Science 288(5473):2028-2031

Magurran AE (2004) Measuring biological diversity. Blackwell Science Oxford, Oxford

Martin DF (1972) Marine chemistry vol 1: analytical methods. Marcel Dekker, New York

Mesnage V, Picot B (1995) The distribution of phosphate in sediments and its relation with eutrophication of a Mediterranean coastal lagoon. Hydrobiologia 297(1):29-41

Meynell PJ (1995) Sustainable management of the coastal ecosystem in the Korangi-Phitti creek (The living marine resources and the environment). Vanguard Books (Pvt) Ltd, Lahore

Monawwar S, Qasim M, Kazi GH (1999) Heavy metal level in fish and shellfish of Karachi coastal area. Pak J Mar Biol 5(2):143-154

Moore RM (1978) The distribution of dissolved copper in the eastern Atlantic Ocean. Earth Planet Sci Lett 41(4):461-468

Muchuweti M, Birkett J, Chinyanga E, Zvauya R, Scrimshaw MD, Lester J (2006) Heavy metal content of vegetables irrigated with mixtures of wastewater and sewage sludge in Zimbabwe: implications for human health. Agric Ecosyst Environ 112(1):41-48

Mukherjee D, Guha D, Kumar V, Chakrabarty S (1991) Impairment of steroidogenesis and reproduction in sexually mature Cyprinus carpio by phenol sulfide under laboratory conditions. Aquat Toxicol 21(1):29-39

Nagaraja P, Kumar MSH, Yathirajan HS, Prakash JS (2002) Novel sensitive spectrophotometric method for the trace determination of cyanide in industrial effluent. Anal Sci 18(9):1027-1030

Navarro AE, Portales RF, Sun-Kou MR, Llanos BP (2008) Effect of $\mathrm{pH}$ on phenol biosorption by marine seaweeds. J Hazard Mater 156(1):405-411
Rubec PJ (1986) The effects of sodium cyanide on coral reefs and marine fish in the Philippines. In: MacLean J, Dizon L, Hosillos L (eds) The first Asian fisheries forum. Asian Fisheries Society, Manila

Rubec PJ, Pratt VR (1984) Scientific data concerning the effects of cyanide on marine fish. Freshw Mar Aquar 7(5):4-6

Saha N, Bhunia F, Kaviraj A (1999) Toxicity of phenol to fish and aquatic ecosystems. Bull Environ Contam Toxicol 63(2):195-202

Scott DA (1989) A directory of Asian wetlands. IUCN, The World Conservation Union Gland, Switzerland

Serpa D, Falcao M, Duarte P, Da Fonseca LC, Vale C (2007) Evaluation of ammonium and phosphate release from intertidal and subtidal sediments of a shallow coastal lagoon (Ria FormosaPortugal): a modelling approach. Biogeochemistry 82(3):291-304

Shahzad A, Khan MA, Shaukat SS, Ahmed W (2009) Chemical pollution profile of Rehri creek area, Karachi (Sindh). J Chem Soc Pak 31:592-600

Vazquez P, Holguin G, Puente M, Lopez-Cortes A, Bashan Y (2000) Phosphate-solubilizing microorganisms associated with the rhizosphere of mangroves in a semiarid coastal lagoon. Biol Fertil Soils 30(5-6):460-468

Verma S, Rani S, Tyagi A, Dalela R (1980) Evaluation of acute toxicity of phenol and its chloro-and nitro-derivatives to certain teleosts. Water Air Soil Pollut 14(1):95-102

Wangersky PJ (1986) Biological control of trace metal residence time and speciation: a review and synthesis. Mar Chem 18(2):269-297

Ward RM (1999) The shorebirds of Gharo Creek and the Indus Delta, Pakistan. Bull Wader Study Group 90:31-34

Wildish D, Keizer P, Wilson A, Martin J (1993) Seasonal changes of dissolved oxygen and plant nutrients in seawater near salmonid net pens in the macrotidal Bay of Fundy. Can J Fish Aquat Sci 50(2):303-311

WWF (2000) The world conservation strategy, biodiversity action plan for Pakistan, a framework for conserving our natural wealth. World Wide Fund for Nature, Government of Pakistan, IUCN

Yin K, Lin Z, Ke Z (2004) Temporal and spatial distribution of dissolved oxygen in the Pearl River Estuary and adjacent coastal waters. Cont Shelf Res 24(16): 1935-1948

Yousuf F, Wasee K (2006) Diversity, distribution and abundance of zooplanktonic larvae in Pakistani waters. Pak J Biol Sci 9(4):610-615

Zahed MA, Aziz HA, Isa MH, Mohajeri L (2010) Effect of initial oil concentration and dispersant on crude oil biodegradation in contaminated seawater. Bull Environ Contam Toxicol 84(4):438-442

Publisher's Note Springer Nature remains neutral with regard to jurisdictional claims in published maps and institutional affiliations. 